\title{
Hydrological Modeling of Aquifers and Their Ground Water Potentials: Implications for Water Resources Planning and Management in Parts of Obio/Akpor L.G.A, Rivers State, Nigeria
}

\author{
Vincent Ezikornwor Weli ${ }^{1}$, Jimmy Adegoke², Ogah Celestine Ndidi1 \\ ${ }^{1}$ Department of Geography and Environmental Management, University of Port Harcourt, Port Harcourt, \\ Nigeria \\ ${ }^{2}$ Department of Geosciences, University of Missouri, Kansas City, USA \\ Email: welivinezi@yahoo.com, adegokej@umkc.edu
}

Received 17 February 2016; accepted 27 March 2016; published 30 March 2016

Copyright (C) 2016 by authors and Scientific Research Publishing Inc.

This work is licensed under the Creative Commons Attribution International License (CC BY). http://creativecommons.org/licenses/by/4.0/

\section{Abstract}

This study examined the hydrological modeling of aquifers and their ground water potentials for the purposes of water resources planning and management. This was done using the electrical resistivity method employing the schlumberger electrode configuration at randomly selected stations to obtain the thicknesses and resistivities of each layer and depth to the presumably conglomeratic sand stone and its resistivity. Findings showed that the top soil layer resistivity values vary from 59.3 to $248.4 \mathrm{ohm}-\mathrm{m}$ and thickness of 0.6 to $3.9 \mathrm{~m}$. The second layer has resistivity values ranging from 45.0 to $743.5 \mathrm{ohm}-\mathrm{m}$ and a thickness range of 1.5 to $13.8 \mathrm{~m}$. The wet sand is characterized by resistivity values ranging from 144.8 to $1930.2 \mathrm{ohm}-\mathrm{m}$ and a thickness range of 3.8 to $65.8 \mathrm{~m}$. The conglomeratic sand/sand stone has resistivity values ranging from 55.8 to 7719.8 $\mathrm{ohm}-\mathrm{m}$. The depth to this bottom layer varies from 6.6 to $89.5 \mathrm{~m}$. Findings indicate that the entire profile is a sedimentary formation represented by lithological units of sand and clayey sand which make for a good groundwater potentials. However, the groundwater potential zones of the study area in terms of transmisivity revealed four distinct classes representing "very good" (Mgbuosimini, Rumuigbo, Okporo, Rumuomasi and Rumuodara), "good" (Alakahia, Rumuodomaya, Oginigba and Rumuola), "moderate" (Aluu, Rumuekeni, Rumuokoro, Rumuobiakani and Rumueme), and "low" (Ogbogoro, Ozuoba, Akpajio, Elelenwo, Eliozu, Rumuepirikon, Rumuokwuta, Rumuebekwe and Rumurolu) groundwater potential in the area. Well logging should therefore be incorporated in borehole development process for safe and sustainable yield of groundwater in Obio/Akpor. 


\section{Keywords}

\section{Aquifers, Water Resources, Sedimentary Formation, Underground Water and Obio/Akpor}

\section{Introduction}

The increased interest in recent years in underground sources of water has led to a need for more intensive studies of the geometry and properties of aquifers [1]. This is because over half of the world's population depends on groundwater for drinking water supplies. For instance, in the United Kingdom about 30\% of the public water supplies are derived from groundwater, in the United states of America about 50\%, Denmark 99\% [2]; Germany 70\% [3]; and in Tanzania, 30\% [4] depend on underground water resources. Geophysics has played a useful part in such investigations for many years and improvements in instruments and the development of better methods is resulting in a widening of its applications. A geophysical model created can be used to support other studies which involve, primarily one-, two-, and three-dimensional modelling. Resistivity imaging is one of the geophysical surveys which have been used to map groundwater contamination and it is widely used for environmental surveys [5]-[8]. This technique has been used to determine the subsurface resistivity anomalies and recently it has become popular for the investigation of water movement in vadose zone. The growing population in Obio/Akpor has been projected to be around 2 million by 2018. And as a result, water supply must be efficient enough to meet the water demand of the inhabitants in the area.

The ground-water hydrology of some parts of Obio/Akpor local government area, however, is not properly understood. Most previous studies on groundwater potential in the area have tended to concentrate on groundwater quality with reference to contamination [9] [10]. There is a variable degree of knowledge and management practice, ranging from almost no data and no action to sound models about aquifer behavior [11]. In addition, little consideration has been given to evaluate the potential for new groundwater uses to affect existing groundwater users. This lack of understanding could hinder efficient and prudent ground-water development. A thorough study to characterize and quantify the ground-water flow system in the area is needed to address these gaps in the study area. This study therefore is an attempt to hydrologically model the aquifers to determine groundwater flow direction and identification of major hydro geologic units.

\section{Geography and Geology of Obio/Akpor}

The study area Obio Akpor L.G.A, Rivers State is delineated between Latitude 4 $30^{\prime}$ and $4^{\circ} 55^{\prime} \mathrm{N}$ and longitudes $6^{\circ} 55^{\prime}$ and $7^{\circ} 00^{\prime} \mathrm{E}$ (Figure 1) within the Niger Delta region of Nigeria. The Niger Delta area has a tropical rainforest climate, with a distinct wet (April-October) and dry (November-March) seasons. The mean annual rainfall ranges from $2000 \mathrm{~mm}$ (inland) to over $4000 \mathrm{~mm}$ at the coast and the area is characterized by five major geomorphic units namely dry flatland \& plains, Sombreiro-Warri deltaic plains with abundant freshwater back swamps, freshwater swamps, meander belts \& alluvial swamps, saltwater or mangrove swamp and active/ abandoned coastal ridges [12]. The proximity of the aquifers to the surface, flat topography, high annual rainfall, and permeable soil media contributes to insignificant runoffs in the site, and implies that the total precipitation goes into storage. This enhances decomposition activities by bacteria and fungi and leaching of contaminants into the aquifer. The area is geologically composed of various Quaternary deposits that overlie the three main stratigraphic units of Benin, Agbada and Akata. The Benin Formation (Oligocene to Recent) is the aquiferous formation in the study area and is exploited for groundwater supplies [12]. Although a depth of $100 \mathrm{~m}$ is most exploited, about $300 \mathrm{~m}$ depth has been exploited for water [13]. The Benin Formation consists essentially of massive and highly porous sands and gravels with a few thin clay intercalations. The uppermost section of the Benin Formation is the Quaternary deposits of about 40 - $150 \mathrm{~m}$ thick and comprises of rapidly alternating sequences of sand and silt/clay with the later becoming increasingly more prominent seawards [14].

The quality of the groundwater is generally good. The occurrence of iron rich water in the Niger Delta is a well-known problem. Although the iron problem is more prevalent in the freshwater and saltwater mangrove swamps, it can sometimes constitute a major problem in some isolated localities in the dry deltaic plains. Unfortunately, the major factors controlling the lateral and vertical occurrence and distribution of high iron content groundwater in the Niger Delta have not been confirmed [15]. Obio/Akpor features a tropical monsoon climate 


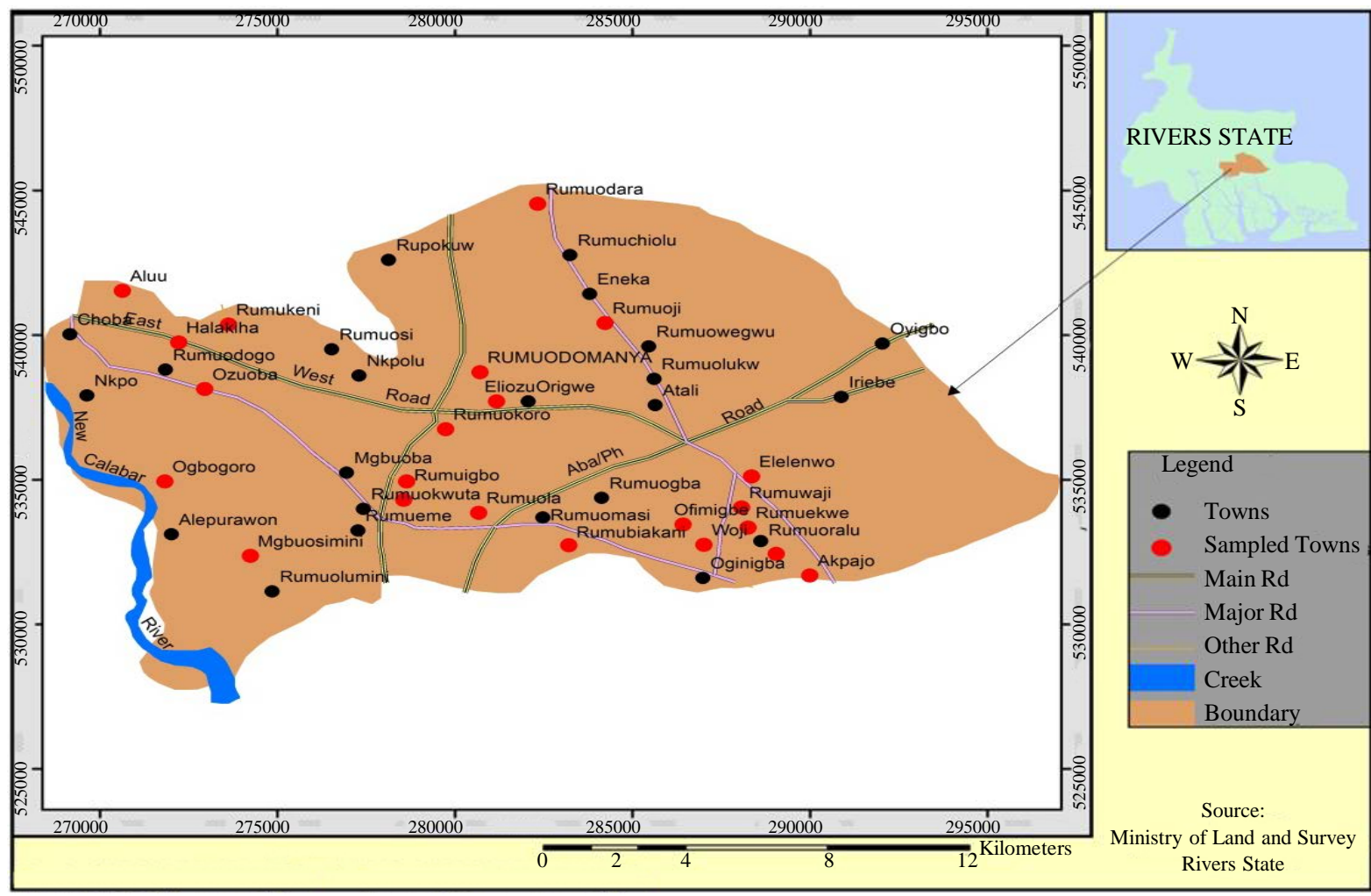

Figure 1. Obio/Akpor, showing sampled towns.

with lengthy and heavy rainy seasons and very short dry seasons [16]. Only the months of December and January truly qualifies as dry season months in the area, although rainfall is experience in all the months. The harmattan, which climatically influences many cities in West Africa, is less pronounced in the area. The region's heaviest precipitation occurs during September with an average of $367 \mathrm{~mm}$ of rain. December on average is the driest month of the year with an average rainfall of $20 \mathrm{~mm}$. Temperatures throughout the year in the city are relatively constant, showing little variation throughout the course of the year. Average temperatures are typically between $25^{\circ} \mathrm{C}-28^{\circ} \mathrm{C}$ in the city.

\section{Methodology}

The Instruments used for data acquisition include Resistivity meter, 12 Volts DC battery, Four steel electrodes, Four realms of insulated conductor cables, Two measuring tapes, Two $250 \mathrm{~g}$ hammer, Four clips, Compass and GPS, Calculator Data sheet, Pencil, Pen, Eraser and sharpener. The electrical resistivity survey was done by dividing the study area into four major groups with each group given its own strike using the Schlumberger electrode configuration at four selected stations for striking within the study area to obtain the layer parameters (resistivities and thicknesses) upon which generations of maps were made. The Schlumberger was used to ensure deep penetration and for logistics of limited man power in the field. The following constitutes the four major groups: Group A (NE-SW Strike) Choba, Ozuoba, Rumuekini, Rumuekini, Mgbuoba, Aluu, Alakahia, Rumuosi. Group B (NE-SW Strike) Rukpokwu, Rumuchiolu, Rumugbo, Rumuodomaya, Atali, Rumuokoro, Elelenwo, Eliozu, Apajo. Group C (NW-SE Strike) Rumuokwuta, Rumueme, Rumuepirikom, Mgbuosumini, Rumuola, Rukpakolusi. Group D (NW-SE Strike), Rumuomasi, Oginigba, Rumuorolu, Rumuobiakani, Rumuogba, Rumuiebekwe, Okporo, Apajo. The 30 VES locations studied were made into 4 profiles (AB, CD, EF and GH respectively) with definite orientations, transversing different geological formations to project a 2-D subsurface geo-electric section along that profile in order to indicate the distinct subsurface layers in the study area. The layers are the top soil, clayey sand, sandy clay, wet sand and presumably conglomeratic sand or sand stone. The geo-electrical resistivity survey of the area was carried out varying the half-current electrode spacing from 1 to $60 \mathrm{~m}$ with a total of 30 VES stations (Figure 1). The electrical resistance measurements were made with the rec- 
tified resistivity meter. The apparent resistivity values were computed using Equation (1).

$$
\rho=\frac{\Delta v}{I} * \pi / 2 p *\left(r^{2}-p^{2}\right)
$$

where $\mathrm{AB} / 2=r$ and $\mathrm{MN} / 2=p$ and $\frac{\pi}{2 p} *\left(r^{2}-p^{2}\right)$ is the geometric factor, $G$.

The apparent resistivity curves were plotted with half current electrode spacing $(A B / 2)$ along the abscissa and apparent resistivity values along ordinate on a bi-logarithmic graph sheet. The apparent resistivity curves were quantitatively interpreted by partial curve matching using 2-layer master curve and a set of auxiliary curves. The resultant starting models were subjected to 1-D inversion using WINREST software. The flow net of the study area was done in order to determine the direction of flow of the groundwater with respect to topography. The values were contoured using SURFER 8 software with the easting, northing, and elevations represented in the X, $\mathrm{Y}$ and $\mathrm{Z}$ components respectively. The layering parameters in terms of layer Resistivities and thicknesses from the interpretation of the apparent resistivity curves were used to construct geo-electric sections along profile lines. The geo-electric section attempts to correlate different layers at each VES point. These Geo-electric profiles were generated using Corel draw software package. The geo-electric profiles are the geo-electric section of each VES location united into one profile with a definite directional orientation. The ordinate " $\mathrm{X}$ " axis represent resistivity and the abscissa "Y" axis represent the depth in metres below ground level. The isopach, overburden coefficient of anisotropy and iso-resistivity maps at each VES point was done using SURFER 8 software. The easting, northing and the top aquifer layer resistivity represent the $\mathrm{X}, \mathrm{Y}$ and $\mathrm{Z}$ components respectively. This is because the lower the resistivity of the top aquifer the higher its groundwater potential. The overburden coefficient of anisotropy $(\Lambda)$ was calculated for each VES station using the layer Resistivities and thicknesses as shown in Equation (2).

$$
\Lambda=\sqrt{\ell t / \ell_{L}}
$$

where;

Longitudinal unit conductance, $S_{i}=h_{i} / \ell_{i}$.

Transverse unit resistance, $T_{i}=h_{i} \cdot \ell_{i}$.

Longitudinal resistivity, $\ell_{L}=h_{i} / s_{i}$.

Transverse resistivity $\ell_{t}=T_{i} h_{i}$.

The empirical relation between aquifer parameter and resistivity as used by [17] and used in this study are established for transforming resistivity distribution into permeability and transmisivity of the aquifer according to the Equation (3) below;

$$
K=0.0538 \mathrm{e}^{0.0072 \rho}
$$

where;

$K=$ Hydraulic conductivity of Aquifer and

$\rho=$ Apparent Resistivity of Aquifer.

\section{Result and Analysis of Findings}

Findings indicate that the flow net of the study area has a series of highs and lows. The areas with the lows (0 $2.4 \mathrm{~m}$ ) can be found around NW of Akpajo, W of Akpajo and N of Rumuokoro and represent low elevation points. Areas with intermediate values $(2.5-3.1 \mathrm{~m})$ can be found around S of Rumuokoro, NE of Okporo, E of Ozuoba, N of Ozuoba and SE of Ozuoba. While areas with high values $(\geq 3.2 \mathrm{~m})$ can be seen around NW of Aluu, S of Aluu, SW of Ozuoba, NW of Ozuoba, S of Eliozu and Okporo and SE of Rumuokoro and represent high elevation points. The highs and the lows are indicators of the elevation and water potential at the water table [18] and the slope of the water table generally follows the contours of the surface topography [19]. Therefore the groundwater will be expected to move from the highs through the intermediary to the lows in the study area (Figure 1).

There are different curve types inferred during the geophysical interpretation of the geo-electric parameters. The sounding curves are typified by AK, A, K, KH, AH, Q, KK, H and AA curve types (Table 1). 
Table 1. Curve types from interpretation of VES data where $\rho$ represent resistivity.

\begin{tabular}{llll}
\hline Area & Curve type & Curve characteristics & No of geoelectric layers \\
\hline $\begin{array}{l}\text { Alakahia, Rumuodara, Rumuodomaya, } \\
\text { Oginigba }\end{array}$ & $\mathrm{AK}$ & $\rho_{1}<\rho_{2}<\rho_{3}>\rho_{4}$ & 4 \\
$\begin{array}{l}\text { Aluu, Ogbogoro, Rumuepiriekom, } \\
\text { Rumuokwuta, Rumuola, Rumuobiakani, }\end{array}$ & $\mathrm{A}$ & $\rho_{1}<\rho_{2}<\rho_{3}$ & 3 \\
$\begin{array}{l}\text { Rumuomasi, } \\
\text { Ozuoba }\end{array}$ & $\mathrm{K}$ & $\rho_{1}<\rho_{2}>\rho_{3}$ & 3 \\
$\begin{array}{l}\text { Rumuekeni, Akpajo, Elelenwon, } \\
\text { Rumuebekwe, Rumurolu, Rumueme }\end{array}$ & $\mathrm{KH}$ & $\rho_{1}<\rho_{2}>\rho_{3}<\rho_{4}$ & 4 \\
$\begin{array}{l}\text { Eliozu } \\
\text { Rumuigbo }\end{array}$ & $\mathrm{AH}$ & $\rho_{1}<\rho_{2}<\rho_{3}<\rho_{4}$ & 4 \\
Rumuokoro & $\mathrm{Q}$ & $\rho_{1}>\rho_{2}>\rho_{3}$ & 3 \\
Mgbuosimini & $\mathrm{KK}$ & $\rho_{1}<\rho_{2}>\rho_{3}>\rho_{4}$ & 4 \\
Okporo & $\mathrm{H}$ & $\rho_{1}>\rho_{2}<\rho_{3}$ & 3 \\
\hline
\end{tabular}

The curve types of the study area are expected to follow the general trend as described below:

$\mathrm{K}$ type-The "K" curve is characterized by decreasing resistivity values with depth. The resistivity value also decreased in the deeper aquifer. This is a typical representation in Ozuoba. $\mathrm{H}$ type-The " $\mathrm{H}$ " curve type is a typical representation in Mgbuosimini where the resistivity value of the first layer is greater than the resistivity of the second layer and resistivity of the second layer is less than that of the third layer. Q type-The "Q" curve shows a continuous decrease in resistivity values from the first layer to the under laying layers. This is a typical curve representation in Rumuigbo. A type-The "A" curve type shows a continuous increase of resistivity values from the first layer down to the under laying layers. This is a typical representation of Aluu, Ogbogoro, Rumuopirikon, Rumuokwuta, Rumuola, Rumuobiakani and Rumuomasi. Others are AK (represented in Alakahia, Rumuodara, Rumuoomaya and Oginigba), KH (represented in Rumuekeni, Akpajio, Elelenwo, Rumuibekwe, Rumurolu and Rumueme), AH (represented in Eliozu), KK (represented in Rumuokoro) and AA (represented in Okporo) curve types. The units of $y$ and $x$ coordinates of the Figures 2-4 below are in meters.

The figures below show typical sounding curves for different stations. However because of space, very few were shown here. Values for $\mathrm{x}$ are measured in meters and y coordinates are measured in ohm-meters as shown (Figures 5-7).

The isopach map of the overburden revealed overburden thicknesses between 0 and $46 \mathrm{~m}$. The overburden as used in this context refers to all materials above the presumably conglomeratic sand/ sand stone. Findings showed that the highs around $\mathrm{E}$ and $\mathrm{S}$ of Eliozu have thick overburden thicknesses ( $\geq 28 \mathrm{~m}$ ) while the lows as seen around SW of Rumuokoro, N and NW of Rumuokoro, N and NE of Okporo, E and SE of Okporo have relatively thin overburden $(0-9 \mathrm{~m})$. Areas with intermediate overburden thicknesses $(10 \mathrm{~m}-27 \mathrm{~m})$ include $\mathrm{E}$ and SE of Rumuokoro, N and SW of Eliozu and W and NW of Okporo. Consequently areas with highs may have a minimal groundwater potential due to a high drill depth for borehole while good and better groundwater yield is expected in areas with average and thick overburden thicknesses respectively due to a fair and smaller drill depth for borehole development in the study area.

The aquifer resistivity of the VES points indicates that the lows ( $\leq 300 \mathrm{ohm}-\mathrm{m})$ are seen around E of Aluu, NE of Akpajo and $\mathrm{N}$ of Eliozu and as such are expected to be good aquifers in contrast to the highly resistive areas ( $\geq 700 \mathrm{ohm}-\mathrm{m}$ ) which include S of Ozuoba, NE of Okporo and SE of Okporo. Areas with intermediate resistivity value ranging between 300 and $600 \mathrm{ohm}-\mathrm{m}$ around $\mathrm{N}$ of Okporo, S of Okporo and NE of Rumuokoro are expected to have fair aquifer qualities (fair groundwater yield).

The overburden coefficient of anisotropy showed that the lows $(\leq 1.15)$ have relatively lesser values compared to the highs $(\geq 1.4)$. The areas with high anisotropy values can be located around SW of Rumuokoro while areas with low anisotropy are located around East of Aluu, NE of Eliozu, SE of Rumuokoro, SE of Okporo and NW of Akpajo. The areas characterized with intermediary values of overburden coefficient of anisotropy can be found around S of Ozuoba, S of Rumuokoro and S of Okporo (1.2 - $1.35 \mathrm{~m})$. According to [20], a higher coefficient of anisotropy implies higher permeability. Thus areas such as SW of Rumuokoro have good groundwater potential in contrast to East of Aluu, NE of Eliozu, SE of Rumuokoro, SE of Okporo and NW where anisotropy is relatively low. 


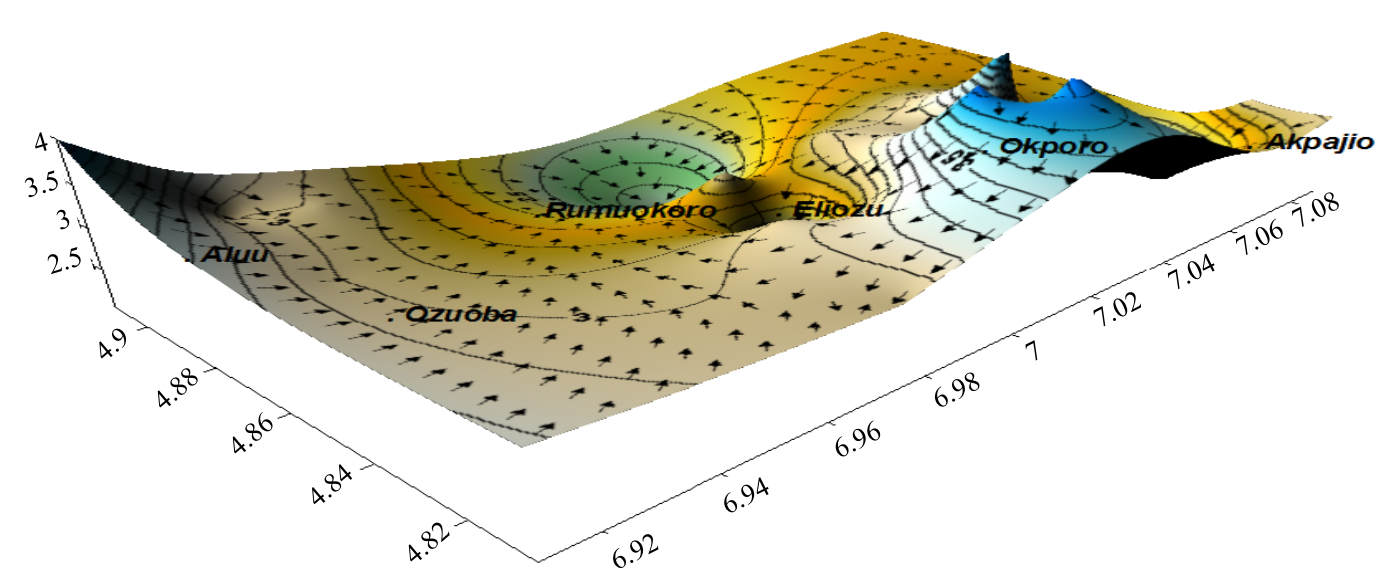

Figure 2. Vector map representing groundwater flow of the area.

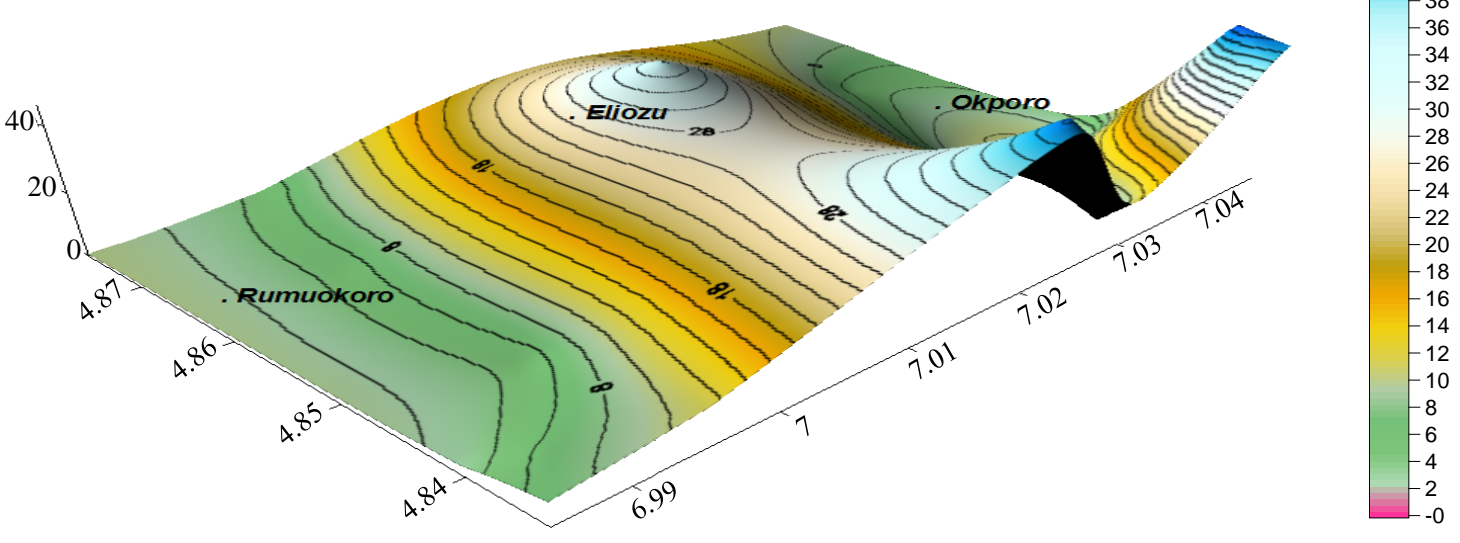

Figure 3. 3D map of overburden.

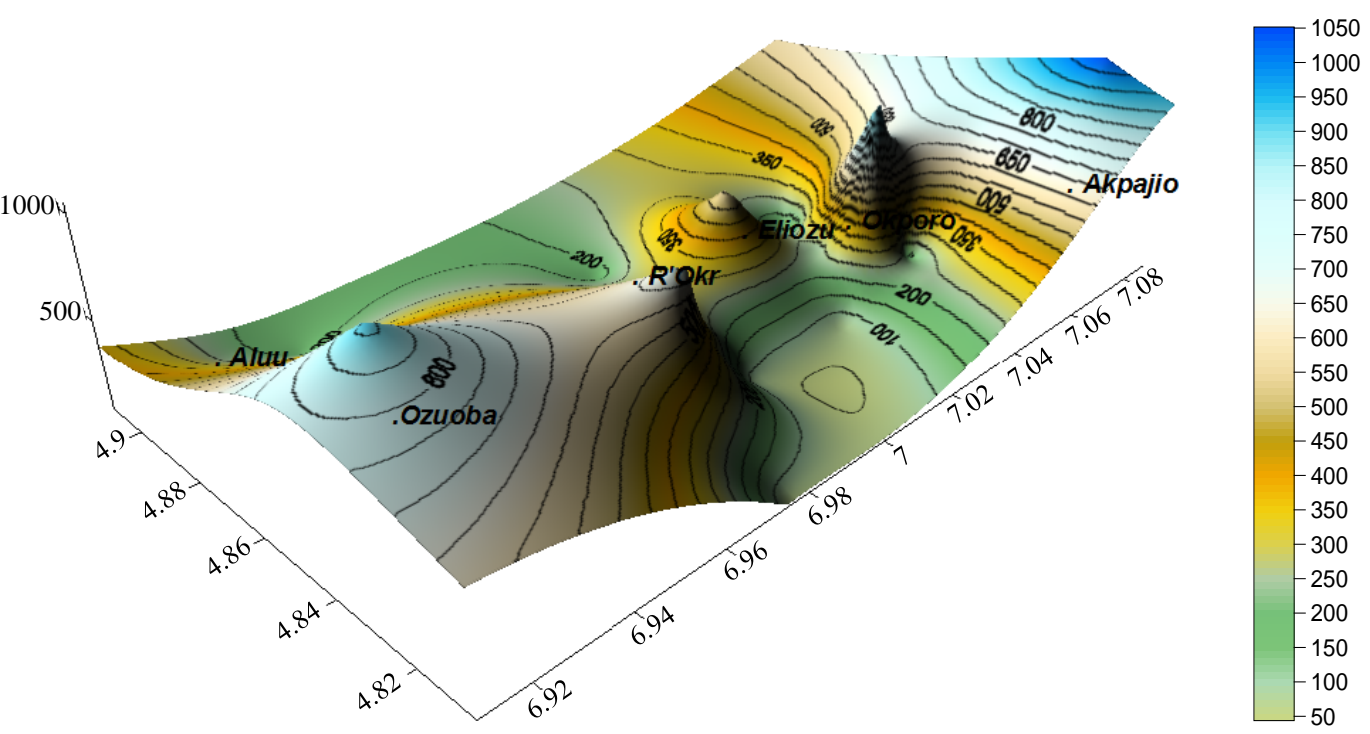

Figure 4. Isoresistivity map of the study area. 


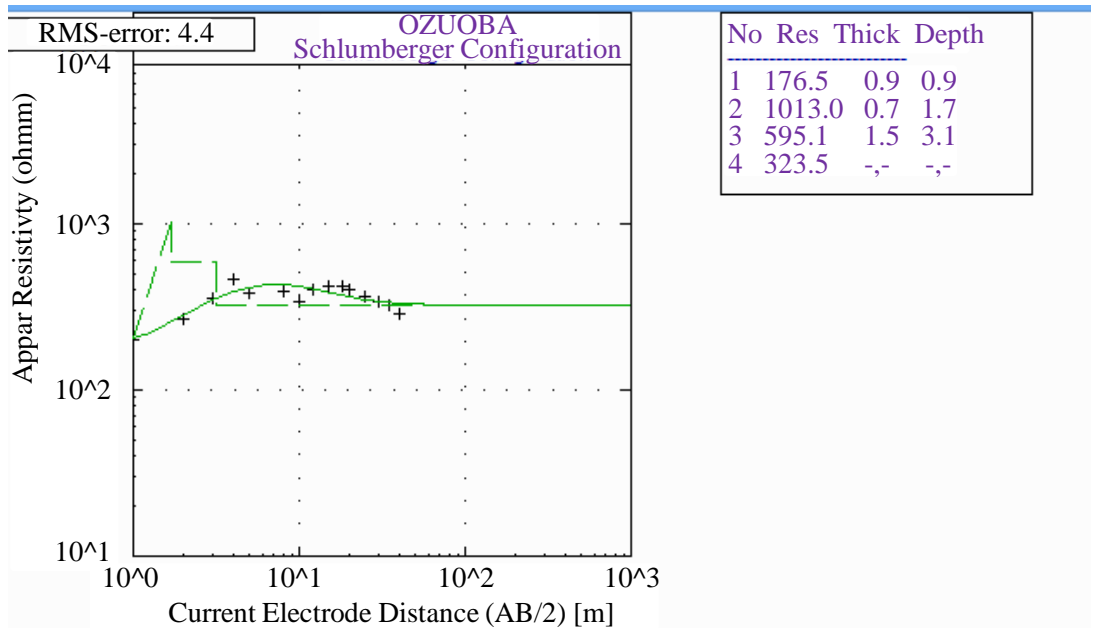

Figure 5. Typical sounding curves for Uzuoba.

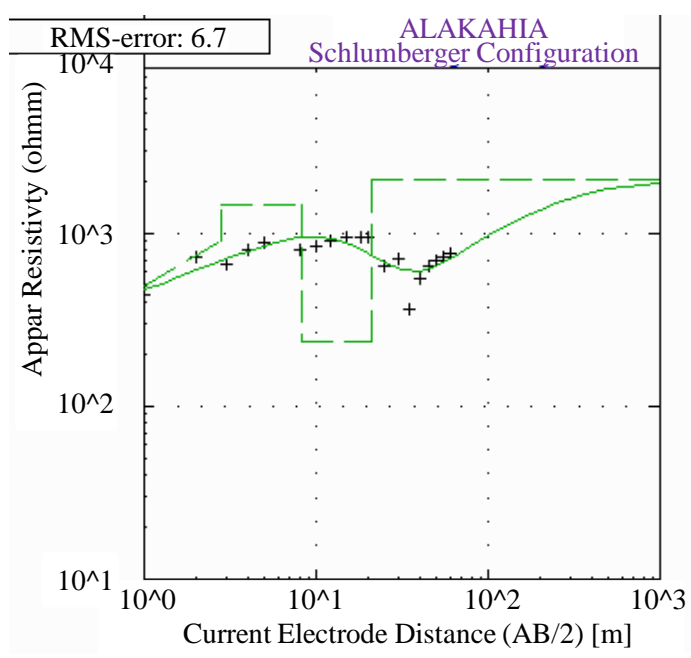

\begin{tabular}{|llll} 
No & Res & Thick & Depth \\
\cline { 1 - 3 } 1 & 415.3 & 0.7 & 0.7 \\
2 & 900.7 & 2.1 & 2.8 \\
3 & 1469.8 & 5.5 & 8.3 \\
4 & 236.8 & 12.8 & 21.2 \\
5 & 2046.7 &,-- &,--
\end{tabular}

Figure 6. Typical sounding curves for Alakahia.

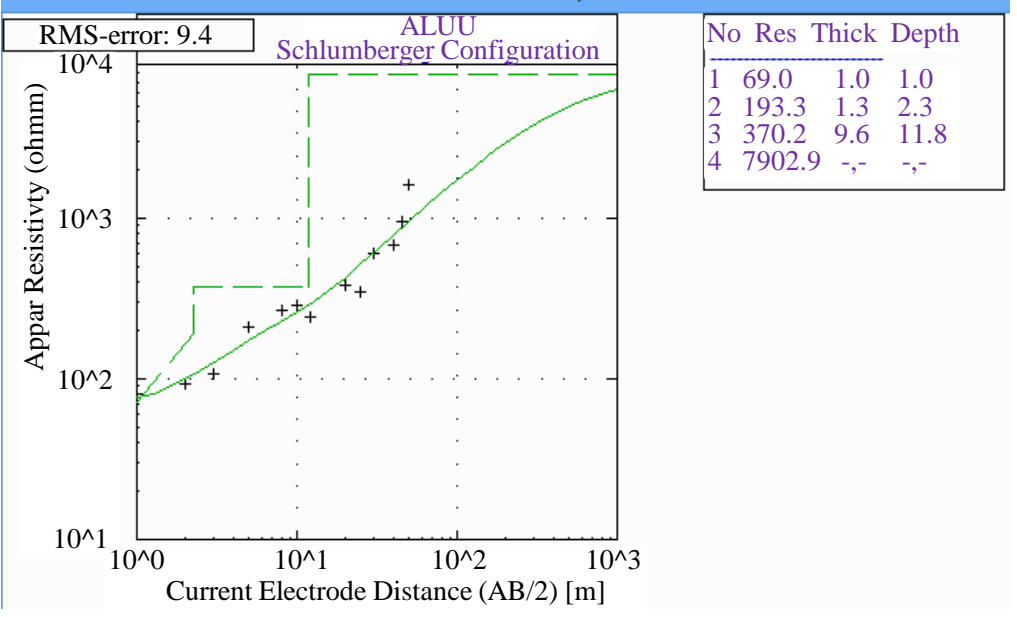

Figure 7. Typical sounding curves for Aluu. 
Findings revealed that the Isopach map of Top Aquifer is characterized by a systematic increase towards the South (SW precisely, $15 \mathrm{~m}$ to $45 \mathrm{~m}$ ) and a decrease towards areas around the North (precisely NE area, below $15 \mathrm{~m}$ ). This implies that areas around the SW with large Top Aquifer thickness will be best suited for prolific borehole yield due to their high ground water recharge. While areas around the NE will have poor ground water recharge.

The profile AB comprises of 5 VES points located at Ozuoba, Alakahia, Rumuekeni, Aluu and Ogbogoro in NE-SW direction. The top soil layer resistivity values vary from 69 - 415 ohm-m and thickness of between 0.6 and $1.0 \mathrm{~m}$. The second layer has resistivity values ranging from 193.3 to $1013.0 \mathrm{ohm}-\mathrm{m}$ with a thickness range of 0.3 to $2.7 \mathrm{~m}$. The wet sand is characterized by resistivity values ranging from 179.3 to $1469.8 \mathrm{ohm}-\mathrm{m}$ and thickness range of 1.5 to $9.6 \mathrm{~m}$. The conglomeratic sand has resistivity value range of 169.3 to $7902.9 \mathrm{ohm}-\mathrm{m}$. The depth to this bottom layer varies from 3.1 to $21.2 \mathrm{~m}$.

The profile CD comprise of 7 VES points located at Eliozu, Elelenwo, Akpajo, Rumuokoro, Rumuigbo, Rumuodomaya and Rumuodara in the E-W direction. The top soil layer has resistivity value range from 56.3 to $2373.1 \mathrm{ohm}-\mathrm{m}$ and thickness range of 0.5 to $3.6 \mathrm{~m}$. The second layer has resistivity range of 172.4 to 5528.8 ohm-m and a thickness range of $1.0 \mathrm{~m}$ to $32.6 \mathrm{~m}$. The third layer also has a resistivity range of between 210.4 and $7410.0 \mathrm{ohm}-\mathrm{m}$ and a thickness range of 0.7 and $13.8 \mathrm{~m}$. The wet sand is characterized by a resistivity value range of 79.7 to $10554.1 \mathrm{ohm}-\mathrm{m}$ and a thickness range of $1.0 \mathrm{~m}$ to $13.3 \mathrm{~m}$.

The conglomeratic sand/sand stone has a resistivity value range of 367.3 to $5770 \mathrm{ohm}-\mathrm{m}$. The depth to this bottom layer varies from 6.7 to $36.5 \mathrm{~m}$.

From the profile findings it can be inferred that the low resistivity anomalies may be due to the presence of clay while the higher resistivity maybe due to the presence of sand. Based on the geo-electrical investigations of the study area, the entire profile is a sedimentary formation represented by lithological units of sand and clayey sand which are good groundwater potentials. The occurrence of alternating sequences of clay and sand deposits call for proper and careful well siting, drilling and development by use of adequate borehole technology despite great potential for groundwater resource in the study area.

Findings indicate that areas where we have high resistivity values turns out to be areas where we have low transmisivity values and vice versa. Some of the areas have high depth to aquifer (VES 21, VES 8, VES 22, and VES 20) which may warrant a high drilling depth for borehole development in the areas. Whereas some of the areas have shallow aquifer (VES18, VES7, VES4, VES5, VES3) which may be easily polluted by contaminated surface runoff in the area. Moreso, some of the areas have large aquifer thickness (VES22, VES17, VES9, VES1, VES16, VES13) which may warrant a high groundwater content. Areas with small aquifer thickness as representedbyVES3, VES4, VES21, VES23, VES19, and VES5 may be expected to have low groundwater content. Also from the contour and 3D transmisivity maps of the probable aquifer distribution represented by Figure 8

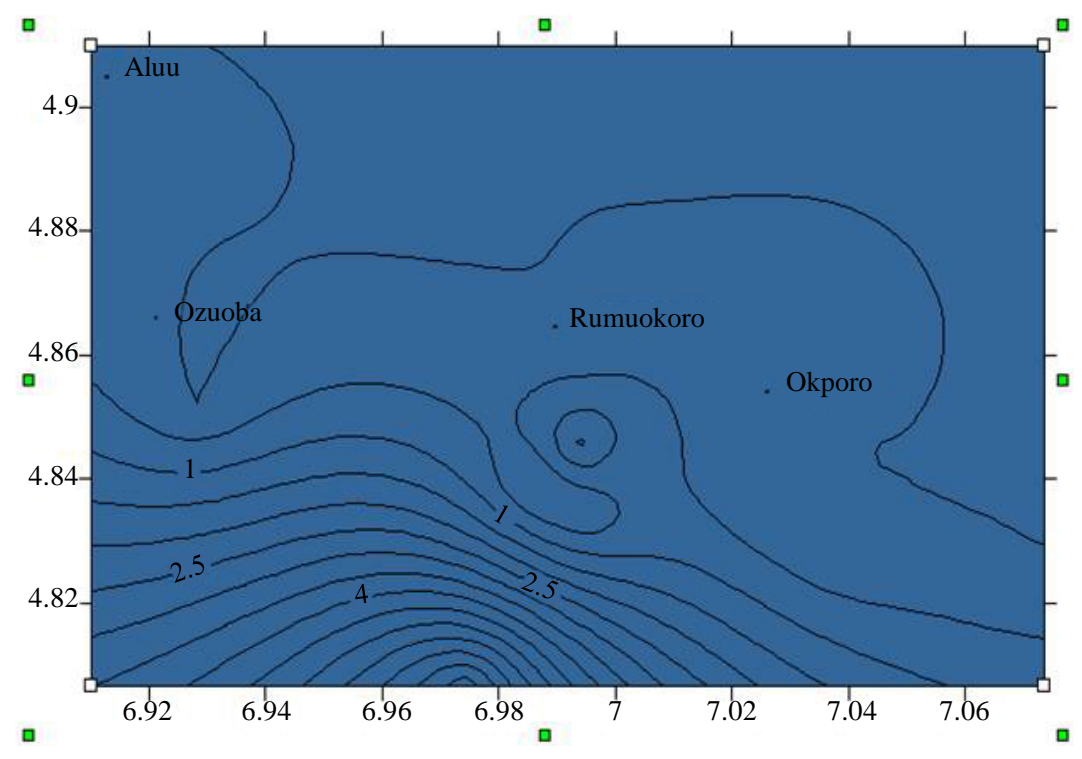

Figure 8. Contour map of top aquifertransmisivity. 
and Figure 3 respectively, it is observed that areas around the SW and due South of the study area have high Transmisivity values $\left(\geq 4.5 \mathrm{~m}^{2} / \mathrm{s}\right)$. These areas are therefore expected to have good groundwater potentials in form of high groundwater yield due to their presumably high discharge. However the groundwater potential zones of the study area in terms of Transmisivity reveals four distinct classes representing "very good" (Mgbuosimini, Rumuigbo, Okporo, Rumuomasi and Rumuodara), "good” (Alakahia, Rumuodomaya, Oginigba and Rumuola), “moderate” (Aluu, Rumuekeni, Rumuokoro, Rumuobiakani and Rumueme), and "low” (Ogbogoro, Ozuoba, Akpajio, Elelenwo, Eliozu, Rumuepirikon, Rumuokwuta, Rumuebekwe and Rumurolu ) groundwater potential in the area.

\section{Conclusion}

The low and higher resistivity anomalies found were attributed to the presence of clay and sand respectively. Similarly, the entire profile is a sedimentary formation represented by lithological units of sand and clayey sand which are good groundwater potentials. The occurrence of alternate sequence of clay and sand deposits demands for proper and careful well sitting, drilling and development despite great potentials for groundwater resource in the study area. Good groundwater yield can be located around SW of the study area, SW of Rumuokoro, N of Rumuokoro, E of Aluu, NE of Akpajo and N of Eliozu. This is because they are characterized by high anisotropy coefficient (i.e. high permeability), high aquifer thickness, high transmisivity and low resistivity. This implies that the aquifers in these areas are expected to be saturated with groundwater and also transmit water at a high rate and capable of supporting groundwater exploration for large scale water supply.

\section{Recommendation}

1) Well logging should therefore be incorporated in borehole development process for safe and sustainable yield of groundwater in the area.

2) It is therefore suggested that boreholes be drilled at Mgbuosimini, Rumuigbo, Okporo, Rumuomasi and Rumuodara, in order to sustain regular water supply in the study area.

3) Pollution Source Release Control should be monitored in the area.

4) Period Groundwater Monitoring is needed.

5) Aggressive Public enlightenment campaign is highly needed.

6) Studies are needed in the following areas.

a) Determination of rates and distribution of groundwater yield.

b) Identification of contaminants of emerging concerns (CECs) in the groundwater resources of the region.

\section{Highlights of the Study}

- Good ground water yield was found around Rumuokoro, Aluu, Akpajo and Eliozu.

- The ground water flow direction is towards NW and W of Akpajo and N of Rumuokoro.

- Clay and sand caused low and high resistivity anomalies respectively.

- Well logging in borehole development process is proposed.

- Alternative source of water supply is needed.

\section{Acknowledgements}

We wish to acknowledge the schlumberger oil servicing company in Port Harcourt for the use of their equipment throughout the period of this study.

\section{References}

[1] Asry, Z., Samsudin, A.R., Yaacob, W.Z. and Yaakub, J. (2012) Groundwater Exploration Using 2-D Geoelectrical Resistivity Imaging Technique at Sungai. Udang, Melaka. Journal of Earth Science and Engineering, 2, 624-630.

[2] Tebbuth (1992) Principles of Water Quality Control. Elsevier Science and Technology Books.

[3] Trauth, R. and Xanthopoulos, C. (1997) Non Point Pollution of Ground Water in Urban Areas. Water Research, 31, 2711-2718. http://dx.doi.org/10.1016/S0043-1354(97)00124-3

[4] Masterson, J.P., Carlson, C.S., Massey, A.J. and Walter, D.A. (2009) Hydrogeology and Simulation of Groundwater 
Flow in the Plymouth-Carver-Kingston-Duxbury Aquifer System South Eastern Massachussets: U.S Geological Survey Scientific Investigation Report.

[5] Griffiths, D.H. and Barker, R.D. (1993) Two-Dimensional Resistivity, Imaging and Modelling in Areas of Complex Geology. Applied Geophysics, 29, 211-226. http://dx.doi.org/10.1016/0926-9851(93)90005-J

[6] Samsudin, A.R., Hamzah, U., Rafek, A.G. and Yaacup, R. (2000) Application of Geoelectrical Resistivity Imaging for Site Investigation. Proceedings Annual Geological Conference, Bali, 375-380.

[7] Samsudin, A.R., Hamzah, U. and Ramli, Z. (2001) Geophysical Investigation of the Olak Lempit Quaternary Basin. In: Geosea Regional Congress, Yogyakarta, 280-282.

[8] Hamzah, U., Samsudin, A.R., Yaacup, R. and Ayub, S.M. (2006) Electrical Imaging of Groundwater Aquifer at Banting, Selangor, Malaysia. Environmental Geology, 49, 1156-1162. http://dx.doi.org/10.1007/s00254-005-0160-6

[9] Nwankwoala, H.O. and Omunguye, M.L. (2012) Geophysical Investigation for Ground Water in Boirikiri and Eastern Bye-Pass Areas of Port Harcourt. The Pacific Journal of Science and Technology, 14, 524-535.

[10] Ujile, A.A. (2013) Evaluating Groundwater Contamination Process and Developing Framework for Qualitative Management in Parts of Nigeria.

[11] Nwankwoala, H.O. (2011) An Integrated Approach to Sustainable Groundwater Development and Management in Nigeria. Journal of Geology and Mining Research, 3, 123-130.

[12] Akpokodje, E.G. (2001) Introduction to Engineering Geology. Pam Unique Publishing Co. Ltd., Port Harcourt, 180181.

[13] Ngah, S.A. (1990) Groundwater Resource Development in the Niger Delta: Problems and Prospect. 6th International IAEC Congress.

[14] Etu-Efeotor, J.O. and Akpokodje, E.G. (1990) Aquifer Systems of the Niger Delta. Journal of Mining and Geology, 26, 279-285.

[15] Port Harcourt Water Corporation (PHWC) (2014) Urban Water Reform and Port Harcourt Water Supply and Sanitation. African Development Bank Group. Reference: P-NG-E00-007.

[16] Weli, V.E. and Worlu, S.O. (2011) Recent Rainstorm Dynamics and Its Implications for Flood Frequency in SubHumid Tropical City of Port Harcourt, Nigeria. Journal of Geographic Thought, 12.

[17] Singh, K.P. (2005) Non-Linear Estimation of Aquifer Parameters from Surficial Resistivity Measurements: Hydrogeology and Earth System Science Discussion (HESSD). 919-927.

[18] Devine, C.E. and McDonell, J.J. (2005) The Future of Applied Tracers in Hydrogeology. Hydrogeology Journal, 13, 255-258. http://dx.doi.org/10.1007/s10040-004-0416-3

[19] Weis, M. and Gvirtzman, H. (2007) Estimating Groundwater Recharge Using Flow Models of Perched Karsticaquifers. Groundwater, 45, 761-773. http://dx.doi.org/10.1111/j.1745-6584.2007.00360.x

[20] Betayanah, A.T. (2006) Use of Electrical Resistivity Methods for Detecting Subsurface Fresh and Saline Water and Delineating Their Interfacial Configurations. A Case Study of the Eastern Dead Sea Coastal Aquifer. Jordan Hydrogeology Journal, 14, 1277-1283. http://dx.doi.org/10.1007/s10040-006-0034-3 